\title{
Universal Assessment Methodology for Evaluating Students' and Teachers' Performance in Academic Institutions
}

\author{
Agbasonu Valerian C., Nwawudu Sixtus E., and Amaechi James C.
}

\begin{abstract}
Evaluating teachers and students are very critical factors in the education process. The problems that exist in this context are problems of identifying the methods of evaluation and adopting the right evaluation techniques for traditional and non-traditional students. This work was motivated by the need for educators in academic institutions to choose the right evaluation technique which is universally accepted in educational or academic institutions. However, this work examines the formative and summative assessment methodologies which exist and recommendations were made. Data will be collected from educators in both government and private owned secondary schools, analyzed using the Likert scale method of data analysis, SPSS statistical package and Microsoft excel spreadsheet package which are advanced software used by social scientists for in-depth analysis and prediction; thereafter, a universally accepted method will be recommended.
\end{abstract}

Index Terms-Evaluation, teachers, students, schools, DATA, software.

\section{INTRODUCTION}

Education is the process of acquiring knowledge, skills, morals or values from people, places, processes or situations Education is the act or process of imparting or acquiring general knowledge, developing the powers of reasoning and judgment, and preparing oneself or others intellectually for mature life [1].

People often confuse education with schooling. Most people think of places like schools, classrooms or colleges when seeing or hearing the word "education". However, the way lots of schools and teachers operate is not necessarily something we can properly call education.

In the past, education in most parts of the world is teacher centered. This made learning boring in many cases. However, modern day teaching and learning is mostly interactive, fun and student centered. Academic institutions have graduated from the teacher centered learning to student centered learning and this can be seen in high schools.

However, education should be undertaken in the belief

Manuscript received November 25, 2017; revised February 10, 2018.

Agbasonu Valerian C. is with IMO State University, Nigeria (e-mail: valpraise@gmail.com).

Nwawudu Sixtus E. is with NESN Humanitarian and Research Initiative, 31 rue Berthelot 4210 Saint-Etienne, France (e-mail: ezenwawudu@yahoo.com).

Amaechi James C. is with the Widow and Orphans Empowerment, 110 Pent City Estate, Lokogoma Abuja, Nigeria (e-mail: berogu12@gmail.com). that all should have the chance to share in life [2]. This commitment to the good of all and of each individual is central to the vision of education explored here, but it could be argued that it is possible to be involved in education without this. We could take out concern for others. We could just focus on process - the wise, hopeful and respectful cultivation of learning - and not state to whom this applies and the direction it takes [2].

Evaluating teachers are usually done by employers to check the areas of improvement. These actions have been criticized by many who believe that students should be given the chance to evaluate their teachers. "A really good student survey can measure what you want to measure," says Ferguson, a senior lecturer in education and public policy at the Harvard Graduate School of Education and the Harvard Kennedy School. "It can reveal what's happening inside classrooms. I'm not sure there's a better way to calibrate the effectiveness of teachers [3]".

Regardless of race, socioeconomic status and other divergent demographics, Ferguson found the students' answers to be serious and remarkably consistent. They recognized good - and lousy - teaching, and they responded accordingly [3].

On the other hand, most educators believe that some learners are too young to evaluate their teachers without being bias.

\section{THEORETICAL BACKGROUND}

As educators may have it, no one spends more time and energy watching the teachers than their students. Students know what's working and what's not working for them as far as learning is concerned. However, in some academic environments, teachers deliver interactive lessons or learners-based lessons, their students also spend most of the time watching themselves, working together and making reasonable decisions.

During or after lessons, students are evaluated in order to measure their level of understanding of the lesson. When we assign a grade to a student, what are we evaluating? Teachers vary in what they consider "fair game" for grading, but most often a grade represents a combined assessment of each student's learning achievement (testing what the student knows or knows how to do), general performance (the quality of work that the student produces for the course), and effort (how hard the student worked in the course).

To reduce the amount of time and energy you and your students spend worrying about, or negotiating, grades, it is 
vital that you provide clear grading guidelines and enforce them fairly [4]. This will help largely during assessments.

On the other hand, Assessment refers to the evaluation of something. When it comes to learning, students are assessed by the educational institution, to analyze their learning graph, their understanding level and progress. It also helps in planning further study material [5].

However, two types of assessment methodologies exist and are discussed below:

\section{A. Formative Assessment}

Formative assessment monitors student learning in order to provide ongoing feedback that can be used by instructors to improve their teaching and by students to improve their learning. More specifically, formative assessments:

1) help students identify their strengths and weaknesses and target areas that need work

2) help faculty recognize where students are struggling and address problems immediately

Formative assessments are generally low stakes, which means that they have low or no point value. Examples of formative assessments include asking students to:

1) draw a concept map in class to represent their understanding of a topic

2) submit one or two sentences identifying the main point of a lecture

3) turn in a research proposal for early feedback

\section{B. Summative Assessment}

Summative Assessments are given periodically to determine at a particular point in time what students know and do not know. Summative assessments are often high stakes, which means that they have a high point value. Examples of summative assessments include:

1) a midterm exam

2) a final project

3) a paper

4) a senior recital

Information from summative assessments can be used formatively when students or faculty use it to guide their efforts and activities in subsequent courses. Table I show formal and iformal aspects of formative and summative assesmets.

\section{Source: [5]}

However, according to an article on "Classroom assessment techniques", in-course assessment techniques are designed to gauge the effectiveness of the teaching and the quality of the learning taking place (and not simply to see who is or isn't studying), they are usually anonymous. These anonymous assignments typically can be completed quickly, and focus on three areas:

1) Students' academic skills and intellectual development (e.g., do students have sufficient background knowledge or academic skills to move onto the next topic?)

2) Students' assessments of their own learning skills (e.g., do students feel prepared to learn new material from the textbook, without classroom review?)

3) Students' reactions to various teaching methods, materials, and assignments (e.g., do students believe the exams fairly cover the material stressed in class?).

Based on this feedback, faculty can adjust their teaching to help students learn. The following are some examples of assessment techniques you might consider using:

1) Documented Problem Solution

Rather than simply requiring students to do a number of problems for homework, the instructor asks students to solve a problem and also to write down step-by-step what they were thinking at each stage of the problem-solving process. Reading through these solutions gives an instructor a sense of how well the students are developing their problemsolving skills and can help the instructor determine how much class or section time should focus on improving this academic skill.

TABLE I: FORMAL AND INFORMAL ASPECTS OF FORMATIVE AND SUMMATIVE ASSESSMENTS

\begin{tabular}{|c|c|c|}
\hline & $\begin{array}{l}\text { Formative } \\
\text { Assessment }\end{array}$ & $\begin{array}{l}\text { Summative } \\
\text { Assessment }\end{array}$ \\
\hline Informal & $\begin{array}{l}\text { Questioning } \\
\text { Feedback } \\
\text { Peer Assessment } \\
\text { Self-Assessment }\end{array}$ & $\begin{array}{l}\text { Essays in uncontrolled } \\
\text { conditions } \\
\text { Portfolios } \\
\text { Coursework } \\
\text { Teacher assessment }\end{array}$ \\
\hline Formal & $\begin{array}{l}\text { Further analysis or } \\
\text { tests, exams } \\
\text { Essays } \\
\text { Target setting }\end{array}$ & $\begin{array}{l}\text { Tests } \\
\text { Exams } \\
\text { Essays in controlled } \\
\text { conditions }\end{array}$ \\
\hline
\end{tabular}

\section{2) Studies of Time Spent Learning}

This technique asks students to estimate, check, document, and reflect on how well they use study time. Using one assignment or activity, students estimate how much time it should take to finish the task and then monitor each other as they complete the assignment. Afterward they write a brief account of the process and the results. In reading these accounts, teachers can gain a sense of how well students use their time and whether students' learning skills are developed sufficiently to handle the course load. Students become much more aware of their habits regarding study time and this awareness usually encourages them to use their study time more effectively.

3) One-Minute Papers

The teacher ends class a few minutes early and asks one or two questions that students answer, on index cards or notebook paper, and hand in. Questions often asked are, "What were the main points of today's class?" or "What point or example in today's lecture would you like to see reviewed or clarified?" Even in a large class, reading through student responses takes relatively little time. At the next class session, teachers can address questions or problems students have raised.

Good assessment techniques both assess and teach; the time spent doing these assignments helps students learn more effectively and efficiently. When students are encouraged to take the time to gauge what they know and how well developed their learning and academic skills are, they begin to recognize the importance of learning how to 
learn, as well as the importance of course content [6].

\section{Methodology}

Two types of methods were adopted in this work:

The first methodology involves conducting a survey among randomly selected learners in a secondary school. The learners required to participate are aged from eight years old. This is because younger learners may not exhibit good sense of judgment. The survey was conducted with the aid of a questionnaire. The questionnaire has three sections: the personal data of respondents, teaching approaches and the students self-evaluation section.

The second methodology involves conducting a survey among randomly selected science teachers in order to give a general evaluation of their learners.

Both surveys will provide adequate information required to recommend or determine the suitable assessment methodologies and even teaching approaches for teachers and learners.

\section{A. Steps Involved in Data Collection}

The following steps were involved in data collection:

\section{> Step 1: Questionnaire Preparation}

To develop a questionnaire that will collect the data you want takes effort and time. However, by taking a step-bystep approach to questionnaire development, you can come up with an effective means to collect data that will answer your unique research question. [7]

The questionnaire was properly prepared and divided into three sections in order to obtain the desired result.

\section{$>$ Step 2: Target respondents}

About eighty learners of various secondary schools were randomly selected to avoid bias. Also, about fifty seventh to twelfth $\left(7^{\text {th }}\right.$ to $\left.12^{\text {th }}\right)$ grade science teachers were randomly selected from numerous secondary schools.

\section{B. Presentation and Analysis of Data}

This section deals with the analysis of the collected data from various secondary schools (Starlight Secondary school, Urban Development secondary school, green spring schools, Pearlville School) Students and teachers were involved. The descriptive statistics of each of the variables will be calculated. These include: the weighted mean and the standard deviation.

\section{GENERAL INFORMATION OF THE RESPONDENTS}

\section{Sex Distribution of the respondents}

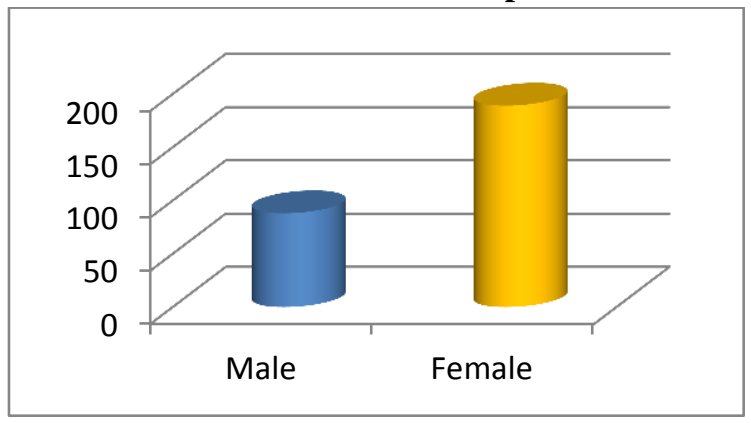

Fig. 1. Sex distribution of the students.

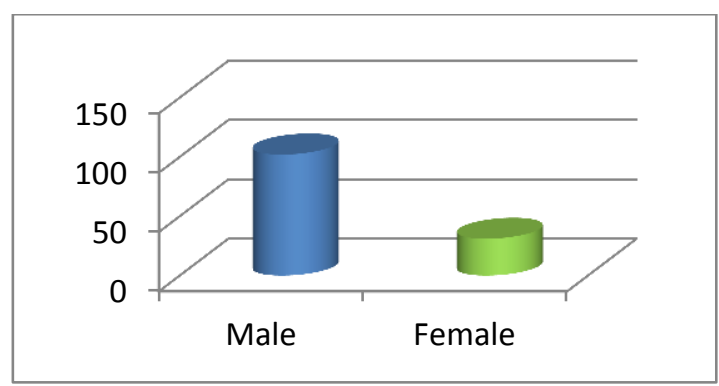

Fig. 2. Sex distributions of the teachers.

\section{Age Distribution of the respondents}

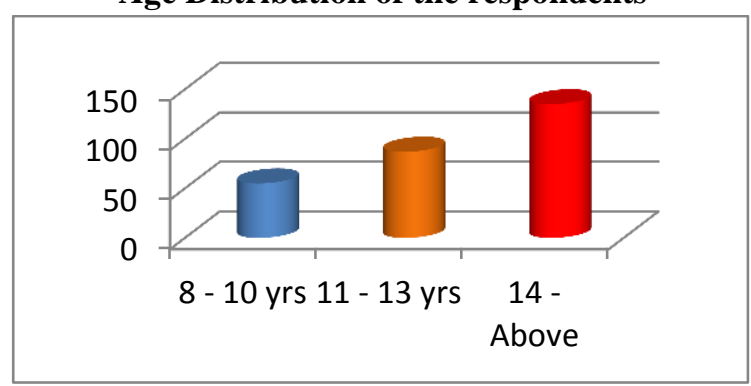

Fig. 3. Age distribution of the students.

\section{Class Level of the Students}

JSS1 - JSS3 $\square$ SS1 - SS3

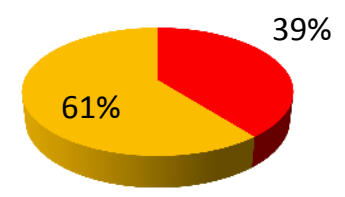

Fig. 4. Class level of the students.

This aspect is very important in obtaining the overall picture of the respondents from which the data were gathered. It includes the respondent's gender shown in Fig. 1 and 2, age shown in Fig. 3, and class shown in Fig. 4.

\section{A. Likert Scale Analysis and Descriptive Statistics}

Selected questions are analyzed below using the Likert scale method of analysis.

Likert scales were developed in 1932 as the familiar fivepoint bipolar response that most people are familiar with today. These scales range from a group of categories-least to most-asking people to indicate how much they agree or disagree, approve or disapprove, or believe to be true or false. There's really no wrong way to build a Likert scale. The most important consideration is to include at least five response categories [8].

Also, this method used generates the weighted means which helps the researcher to determine the level of acceptance of a particular opinion. The weighted mean is shown in Table II, III, IV and V.

From the data obtained Tables II, III, IV and V, the students highly agree that their interests were stimulated by the instructors. They also highly agree that their instructors were organized and prepared for their class, and encouraged discussions. However, the students moderately agree that their instructors managed classroom time and pace well, demonstrated in-depth knowledge of the subjects they taught and challenged students to do their best work. 
TABLE II: TABLE SHOWIng MEAN SCORES AND STANDARD DEVIATIONS OF RESPONSES ON TEACHING APPROACHES ADOPTED FOR STUDENTS

\begin{tabular}{|c|l|c|c|}
\hline $\mathbf{S} / \mathbf{N}$ & \multicolumn{1}{|c|}{ Teaching Approaches } & Mean & SD \\
\hline $\mathbf{1}$ & $\begin{array}{l}\text { The instructor stimulated my interest in the } \\
\text { subject }\end{array}$ & $\mathbf{4 . 0 5}$ & 54.57 \\
\hline $\mathbf{2}$ & $\begin{array}{l}\text { The instructor managed classroom time and } \\
\text { pace well }\end{array}$ & 3.68 & 39.78 \\
\hline $\mathbf{3}$ & $\begin{array}{l}\text { The instructor was organized and prepared for } \\
\text { every class }\end{array}$ & $\mathbf{4 . 1 3}$ & 59.98 \\
\hline $\mathbf{4}$ & $\begin{array}{l}\text { The instructor encouraged discussions and } \\
\text { responded to questions }\end{array}$ & $\mathbf{4 . 0 2}$ & 51.18 \\
\hline $\mathbf{5}$ & $\begin{array}{l}\text { The instructor demonstrated in-depth } \\
\text { knowledge of the subject. }\end{array}$ & 3.47 & 26.02 \\
\hline $\mathbf{8}$ & $\begin{array}{l}\text { The instructor challenged students to do their } \\
\text { best work. }\end{array}$ & 3.47 & 24.34 \\
\hline
\end{tabular}

Note: $\mathbf{1 . 0 0}-\mathbf{2 . 9 9}=$ low; $3.00-3.99=$ moderate; $4.00-\mathbf{5 . 0 0}=\mathbf{~ h i g h}$

TABLE III: TABLE SHOWING MEAN SCORES AND STANDARD DEVIATIONS OF RESPONSES ON SELF-ASSESSMENTS OF THE STUDENTS

\begin{tabular}{|c|c|c|c|}
\hline $\mathbf{S} / \mathbf{N}$ & Self-Assessments & Mean & SD \\
\hline & $\begin{array}{l}\text { I have improved efficiently through the } \\
\text { science teacher's acts of: }\end{array}$ & & \\
\hline 4 & Inviting questions from learners after lessons & 3.05 & 20.84 \\
\hline 5 & Conducting weekly/monthly class oral quiz & 4.01 & 50.3 \\
\hline 6 & $\begin{array}{l}\text { Conducting weekly/monthly class written } \\
\text { quiz }\end{array}$ & 3.90 & 47.77 \\
\hline 7 & $\begin{array}{l}\text { Providing challenging assignments and } \\
\text { worksheets }\end{array}$ & 3.89 & 45.75 \\
\hline 8 & $\begin{array}{l}\text { Ensuring that learners defend their } \\
\text { assignments and scores }\end{array}$ & 3.45 & 19.96 \\
\hline 9 & $\begin{array}{l}\text { Providing puzzles, brain teasers and riddles } \\
\text { relating to the lesson being taught }\end{array}$ & 4.14 & 56.82 \\
\hline 10 & Conducting inter-class or intra-class quizzes & 3.52 & 37.04 \\
\hline
\end{tabular}

TABLE IV: TABLE SHOWING MEAN SCORES AND STANDARD DEVIATIONS OF RESPONSES ON EVALUATION APPROACHES USED BY TEACHERS

\begin{tabular}{|c|l|c|c|}
\hline S/N & \multicolumn{1}{|c|}{ Evaluation Approaches } & Mean & SD \\
\hline $\mathbf{2}$ & $\begin{array}{l}\text { Many students improved because of the type } \\
\text { of difficult questions given to them as } \\
\text { assignments }\end{array}$ & 2.47 & 27.72 \\
\hline $\mathbf{3}$ & $\begin{array}{l}\text { By drawing objects, students were able to } \\
\text { identify them }\end{array}$ & $\mathbf{4 . 0 3}$ & 55.49 \\
\hline $\mathbf{4}$ & $\begin{array}{l}\text { The oral quiz helped the students to achieve } \\
\text { high marks }\end{array}$ & $\mathbf{4 . 0 8}$ & 54.89 \\
\hline $\mathbf{6}$ & $\begin{array}{l}\text { Inter class quiz have helped the students } \\
\text { greatly }\end{array}$ & 3.81 & 46.11 \\
\hline $\mathbf{7}$ & $\begin{array}{l}\text { The class topics were covered because the } \\
\text { students read ahead of the teacher }\end{array}$ & 3.22 & 26.92 \\
\hline
\end{tabular}

Note: $\mathbf{1 . 0 0}-\mathbf{2 . 9 9}=$ low; $3.00-3.99=$ moderate; $4.00-\mathbf{5 . 0 0}=$ high

The data above shows that providing puzzles, brain teasers and riddles relating to the lesson being taught greatly helped the learners. The students also highly agree that conducting weekly/monthly class oral quiz affected them positively. However, the students moderately agree that they have improved through the teacher's act of inviting questions from learners after lessons, conducting weekly/monthly class written quiz, providing challenging assignments and worksheets, ensuring that learners defend their assignments and scores, and conducting inter-class or intra-class quizzes.

From the table above, the teachers highly agree that by drawing objects, students were able to identify, name and classify objects. Also, they highly agree that the oral quiz helped the students to achieve high marks. On the other hand, the teachers moderately agree that inter class quiz have helped the students greatly and that class topics were covered because the students read ahead of the teacher. On the other hand, the teachers disagree to a large extent that many students improved because of the type of difficult questions given to them as assignments.

TABLE V: TABLE SHOWING MEAN SCORES AND STANDARD DEVIATIONS OF RESPONSES ON SELF-APPRAISAL OF TEACHERS

\begin{tabular}{|c|l|c|c|}
\hline S/N & \multicolumn{1}{|c|}{ Self-Appraisal } & Mean & SD \\
\hline 2 & $\begin{array}{l}\text { I used methods that effectively spread } \\
\text { questions throughout the class }\end{array}$ & 3.61 & $\begin{array}{c}30 . \\
29\end{array}$ \\
\hline \multirow{2}{*}{4} & $\begin{array}{l}\text { In planning my lessons, consideration is } \\
\text { given to relating my strategy to the } \\
\text { objectives of the lesson }\end{array}$ & 3.36 & $\begin{array}{c}26 . \\
01\end{array}$ \\
\hline \multirow{2}{*}{6} & $\begin{array}{l}\text { I use assignment sheets and programmed } \\
\text { learning materials when and where } \\
\text { appropriate }\end{array}$ & 3.35 & 33. \\
\hline \multirow{5}{*}{7} & $\begin{array}{l}\text { My assignments require students to } \\
\text { comprehend ideas, apply these ideas, } \\
\text { analyze, synthesize and evaluate information } \\
\text { rather than simply memorize and reproduce } \\
\text { facts. }\end{array}$ & $\mathbf{4 . 0 8}$ & $\begin{array}{c}54 . \\
39\end{array}$ \\
\hline 8 & $\begin{array}{l}\text { I use student achievement as one measure of } \\
\text { my teaching effectiveness }\end{array}$ & 3.85 & 42. \\
\hline
\end{tabular}

Note: $1.00-\mathbf{2 . 9 9}=$ low; $3.00-3.99=$ moderate; $4.00-\mathbf{5 . 0 0}=\mathbf{~ h i g h}$

The data on self-appraisal of teachers above shows that the teachers highly agree that their assignments are comprehensive and adequate. The data also shows that the teachers moderately agree that they:

1) Use methods that effectively spread questions throughout the class.

2) Make considerations to relate their strategies to the objectives of the lesson when planning the lessons.

3) Use assignment sheets and programmed learning materials when and where appropriate.

4) Use student achievement as one measure of teaching effectiveness.

\section{B. Discussion of Results}

The results collected above show that there exists suitable evaluation methods and teaching approaches which educators can adopt. Some of the methods discovered are either formative or summative assessment techniques. Since the students highly agree that their interests were stimulated by the instructors and that their instructors were organized and prepared for their class, it clearly shows that their teachers were highly qualified for their jobs. This also shows that there is a positive relationship between the students and their teachers.

Although the students moderately agree that their instructors managed classroom time and pace well, demonstrated in-depth knowledge of the subjects they taught and challenged students to do their best work, there is need for the teachers to improve their efforts on time management.

On the other hand, providing puzzles, brain teasers and riddles relating to the lesson being taught greatly helped the learners according to the data obtained. The students highly agree that conducting weekly/monthly class oral quiz affected them positively. This shows that teachers should be encouraged to use games and related strategies during instructions. The students moderately agree that they have improved through the teacher's act of inviting questions from learners after lessons, conducting weekly/monthly 
class written quiz, providing challenging assignments and worksheets, ensuring that learners defend their assignments and scores, and conducting inter-class or intra-class quizzes.

There is need for teachers to keep conducting inter class quiz as this helps the students. In the Netherlands, the teacher educators themselves have taken responsibility in safeguarding the quality of their profession by developing a professional standard and a professional register for teacher educators [9].

It is also observed that the teachers highly agree that by drawing objects, students were able to identify, name and classify objects. Also, they highly agree that the oral quiz helped the students to achieve high marks. This finding from the teacher's perspective also conforms to the earlier findings from the students on the need for oral quiz.

\section{Interpretation of Results}

It can be interpreted that providing puzzles, brain teasers and riddles relating to the lesson being taught greatly help the learners. Also, teachers are encouraged to conduct weekly/monthly class oral quiz because they affected students positively. Instructors being organized and prepared for every class also affects learners. It can also be interpreted that providing assignments that require students to comprehend ideas, apply these ideas, analyze, synthesize and evaluate information rather than simply memorize and reproduce facts, helps the students as well as the teacher during self-evaluations.

\section{SUMMARY}

Since the discovery of formal education in the history of mankind, numerous studies on evaluation techniques and teaching approaches have been carried out. However, in evaluating teachers and students, it is important to take experience into account. If a teacher is new to teaching or the student new into a school, they may still be learning about various aspects of being a good teacher or student, teaching/learning skills, student interaction, and departmental expectations. There is need for continual evaluation of teachers and students in the field.

\section{A. Conclusion}

Neglecting the teaching profession is one of the greatest mistakes any nation will make. In almost all countries, concern is expressed about the quality of teacher educators and concrete evaluation methods for improvement exist. Several countries have some kind of national legislation on the criteria for entering the profession of teacher educators. In most cases these criteria and proposals refer to the academic degree that is required for teacher educators. Findings indicate these criteria are not only applied to teacher educators but are aimed at all teachers in higher education. More specific criteria are the local responsibility of teacher education institutes. These criteria play a role in accreditation procedures for institutions or programmes. In only a few countries national professional standards or an ethical code for teacher educators exist [10].

\section{B. Recommendation}

There is overwhelming evidence from the study that show that students can evaluate their teachers and teachers can as well evaluate their students. The following recommendations are made:

1) Instructors are encouraged to organize themselves and get prepared for every class. The right instructional resources should be put in place as students value organization in learning.

2) There is need for teachers to challenge students to do their best in all works as this stimulates their interests.

3) Also, conducting weekly/monthly class oral quiz, providing challenging assignments and worksheets, ensuring that learners defend their assignments and scores and providing puzzles, brain teasers and riddles relating to the lesson being taught are some of the motivating factors to students.

4) Students on the other hand, are advised to pay proper attention to instructions and complete their assignments as at when due.

5) All teachers are encouraged to conducting weekly/monthly class written or oral quiz as this helps the students which do not like writing

\section{Area of Further Work}

The follow up article will focus on the demystification of mathematics. The work will examine measures which should be adopted in order to make mathematics easier.

\section{REFERENCE}

[1] Reference [Online]. Education. Available: https://www.reference.com/education/education1a27ff74d1eacc59\#full-answer

[2] J. W. Ellis, "Informal education - A Christian perspective," in Using Informal Education, T. Jeffs and M. Smith eds. Buckingham: Open University Press, 1990.

[3] AASA: The school superintendents association. [Online]. Available: http://www.aasa.org/content.aspx?id=32692

[4] Teaching Commons Evaluating Students. [Online]. Available: https://teachingcommons.stanford.edu/resources/teaching/evaluatingstudents

[5] Formative Summative. [Online]. Available: https://www.cmu.edu/teaching/assessment/basics/formativesummative.html

[6] P. Black, C. Harrison, C. Lee, B. Marshall, and D. William, Assessment for Learning: Putting It into Practice, Berkshire, England: Open University Press, 2003.

[7] Wikihow. Develop-a-Questionnaire-for-Research. [Online]. Available: http://www.wikihow.com/Develop-a-Questionnaire-for-Research

[8] U. Jakobsson, "Statistical presentation and analysis of ordinal data in nursing research," Scandinavian Journal of Caring Sciences, vol. 18, pp. 437-440, 2004.

[9] B. Koster and J. Dengerink, "Towards a professional standard for Dutch teacher educators," European Journal of Teacher Education, vol. 24 , no. 3 , pp. 343-354, 2001.

[10] C. Ballantyne, "Online evaluations of teaching: An examination of current practice and considerations for the future," New Directions for Teaching and Learning, vol. 96, pp. 103-112, 2003.

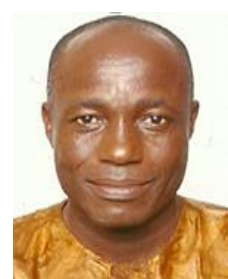

Agbasonu Valerian C. (Ambp) is a lecturer of the Department of Computer Science at Imo State University Owerri. $\mathrm{He}$ has the $\mathrm{PhD}$ in computer/information system, from American Heritage University of Southern California USA; the $\mathrm{PhD}$ in computer science, from Imo State University Nigeria; the M.Sc. in computer science from Ambrose Ali University, Ekpoma, Nigeria; the PGD in computer science from Federal University of Technology/CCE Owerri; the PGD Education and the B.Sc. hons in statistics from University of Nigeria, Nuskka.

Dr. Agbasonu has authored and co-authored many textbooks and published many articles in reputable local and international journals. He is a member of many professional bodies like Computer Professionals of 
Nigeria (CPN), International Society of Telemedicine and eHealth (ISFTEH)

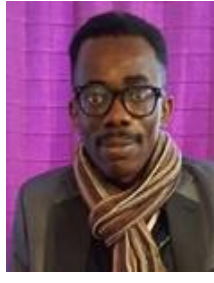

Nwawudu Sixtus Ezenwa was born in 1979. He has the B. Tech degree in computer science, diploma in French language, culture and civilisation from Université Jean Monnet, France, the M.Sc. in biometrics, optics, image, vision and multimedia from Université Paris-Est, Créteil (UPEC), France. His current research interests are image and signal, data mining, 3D visualization, bioinformatics, image and signal, E-medicine etc.

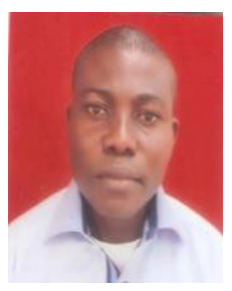

James C. Amaechi is a graduate of computer science from Anambra State University of Science and Technology, Uli, Anambra State, Nigeria. He currently works at Widows and Orphans Empowerment, Abuja, Nigeria. 